\title{
Clinical experience with trisomies 18 and $13^{1}$
}

\author{
M. E. HODES, JUNE COLE, C. G. PALMER, AND TERRY REED \\ From the Department of Medical Genetics, Indiana University School of Medicine, Indianapolis, Indiana \\ 46202, U.S.A.
}

SUMmARY The clinical, cytogenetic, dermatoglyphic, and postmortem observations of the 29 cases of $\overrightarrow{\vec{\omega}}$ trisomy 18 and 19 cases of trisomy 13 seen in the Department of Medical Genetics from 1963-76 ares summarised. Chromosomes were studied in all and 30 were banded. One patient had tertiary trisomyō 18 and 8 had translocations of chromosome 13. The features of these patients are described and the $\vec{r}$ syndromes compared with each other and summaries found in the literature.

Since Patau et al. (1960) and Edwards et al. (1960) described the $\mathrm{D}$ and $\mathrm{E}$ trisomy syndromes, many individual cases and several series of patients have been reported. D trisomy has been reviewed by Lazyuk et al. (1974), Taylor (1968), and Taylor and Polani (1964). Series of cases of trisomy E were reviewed by Butler et al. (1965) and Taylor (1968), and the standard reference works of Smith (1976) and Bergsma (1973) summarise the salient features of each syndrome. These include cardiac, ear, and mental abnormalities in both syndromes; prominent occiput, micrognathia, clenched hand, low arch dermal ridge pattern, limited hip abduction, and prominent heels in trisomy $\mathrm{E}$; and microphthalmia, cleft lip and palate, polydactyly, scalp defects, capillary haemangiomata, and colobomata of the iris in trisomy D. It is apparent that, though each of these syndromes has unique clinical findings, there are many abnormalities that are common to both and the total clinical presentation can be variable. This variability sometimes makes clinical diagnosis difficult and on rare occasions may even lead to confusion of the two syndromes.

Between 1963 and 1976 the Department of Medical Genetics of Indiana University clinically and cytologically evaluated 29 cases of trisomy 18 and a series of 19 patients with trisomy 13 . Karyotypes of banded chromosomes were obtained for 15 of the trisomy 18 patients and 15 of those with trisomy 13 . Included among these patients is one with a translocation in which it appeared that there was partial trisomy of most of the long arm of chromosome 18 and 8 cases

${ }^{1}$ This is publication No. 77-4 from the Department of Medical Genetics and was supported in part by the Indiana University Human Genetics Center, PHS GM 21054 and Dental Genetics Training Grant PHS DE 00007.

Received for publication 18 April 1977 with translocations involving chromosome 13 . This $\vec{T}$ paper offers a summary of the findings in this series of trisomic individuals. The summary includes clinical, dermatoglyphic, and postmortem data, and the relation of these to the karyotype of the patients.

\section{Subjects and methods}

All cases of trisomy D or E listed in the departmentals files and proved by chromosomal studies wereō summarised with the exception of 1 questionable caseo of partial trisomy 18. Dermatoglyphic studies and $\stackrel{\mathbb{Q}}{\varrho}$ chromosomal investigations (with one exception) $\overrightarrow{\vec{D}}$ were done by the authors. Clinical data were obtained 3 from departmental and hospital records. The patients were all seen by one or more members of the? Department of Medical Genetics. Since there were several physicians involved, the findings which wereo reported are not always uniform. The data are sum- $-\overline{7}$ marised in the Tables ${ }^{1}$ and briefly discussed in the 'Results' section.

\section{CLINICAL FINDINGS}

The principal clinical findings in the 29 cases of $\supset$ trisomy $\mathrm{E}$ are summarised in Table 1 and in the 19 으‥

1 Note to Tables
When an abnormality was specifically mentioned it is indicated by a
1 in the tables. When there was specific notation of the absence of the
abnormality, a 0 is entered in the table. When the feature was either not
mentioned or only a general description, such as 'face normal', was
encountered, no entry was made in the tables. On occasion conflicting
observations were reported, a value judgment was made as to the
reliability of the observers, and the entry made accordingly. Inability
to render judgment or doubtful observations are indicated by a '?'. Anç
entry of 11 in Tables 5 and 6 indicates bilateral occurrence of derma-?
toglyphic variables, while 01 indicates unilateral occurrence on the
right, 10 unilateral occurrence on the left, and 00 corresponds to
bilateral absence of the feature. A '-' before or after a single number
indicates that only the left or right pattern, respectively, was discernible.
8 


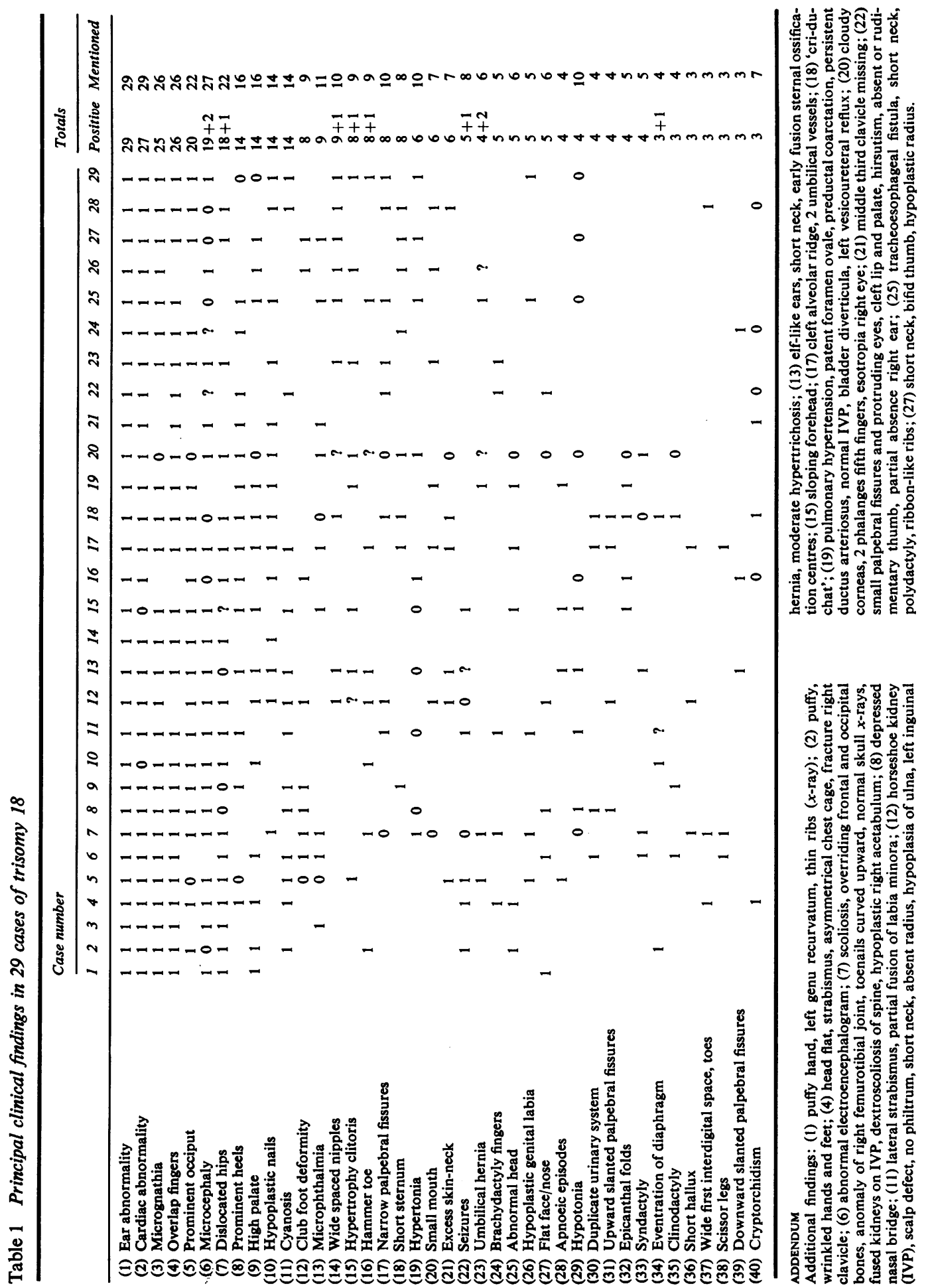




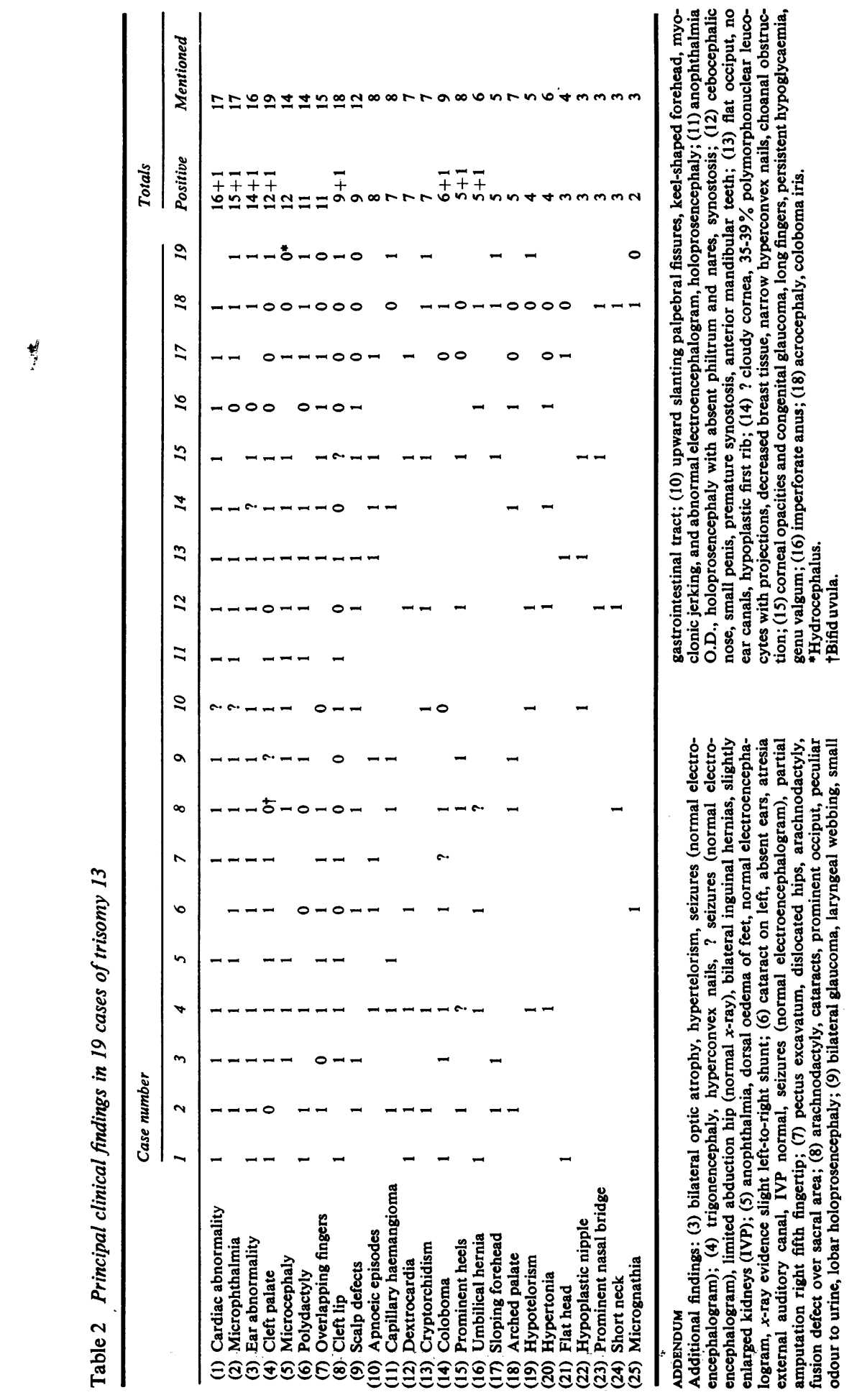


cases of trisomy $D$ in Table 2. The observations are listed in order of frequency of observation, and are combined into broad, differentiable categories. Thus, children with murmurs, heart failure,- and $x$-ray evidence of heart disease are included under 'cardiac abnormalities', and the entry 'ear abnormalities' includes both malformed and low-set auricular appendages.

Tables 1 and 2 list a number of the congenital anomalies found in these patients. Cardiac and ear anomalies of some form were present in almost every case in both syndromes. However, there was often considerable disagreement among observers concerning the nature of the cardiac lesions. Of the other facial abnormalities, microphthalmia was reported in most of the trisomy 13 patients and micrognathia in those with trisomy 18 . Cleft palate alone, cleft lip alone, or both together were almost limited to the trisomy 13 group, though among the trisomy 18 patients, case 17 (Table 1) had a cleft alveolar ridge and case 22 a cleft lip and palate. Microcephaly was common to both conditions, but scalp defects were mainly found in trisomy 13 (exception, case 12 of trisomy 18) and a prominent occiput in trisomy 18.
Other abnormalities of the head, such as hypotelorism, were reported in fewer than one-third of the trisomy 13 patients.

The most prominent disorders of the extremities were overlapping fingers $(90 \%$ of trisomy 18 and $58 \%$ of trisomy 13) with polydactyly usually present in patients with trisomy 13 (exception, cases 25 and 27 of trisomy 18). Dislocated hips, prominent heels, hypoplastic nails, hammer toe, and club foot deformities were common among the trisomy 18 cases, whereas of these only prominent heels was mentioned for those with trisomy 13.

Other clinical findings that served to differentiate the conditions were capillary haemangiomas, colobomas of the iris, and umbilical hernias among the trisomy 13 cases, and wide spaced nipples, clitoral hypertrophy, and short sternum among the patients with trisomy 18. Cryptorchidism was a universal finding $(100 \%)$ in males with trisomy 13 and was present in $43 \%$ of the males with trisomy 18 .

Tables 3 and 4 summarise the available data on sex, race, birthweight, life span, parental age, and karyotype. The birthweights were generally reduced or average but ranged widely, with both mean and

Table 3 Race, birthweight, life span, parental age, and chromosomal findings of 29 cases of trisomy 18

\begin{tabular}{|c|c|c|c|c|c|c|c|c|}
\hline $\begin{array}{l}\text { Case } \\
\text { no. }\end{array}$ & Race & $\begin{array}{l}\text { Birthweight } \\
(\mathrm{g})\end{array}$ & $\begin{array}{l}\text { Life span } \\
\text { (days) }\end{array}$ & $\begin{array}{l}\text { Mother's age } \\
(y)\end{array}$ & $\begin{array}{l}\text { Father's age } \\
\text { (y) }\end{array}$ & $\begin{array}{lc}\text { Cell counts } \\
46\end{array}$ & $\begin{array}{l}\text { Type } \\
\text { banding }\end{array}$ & Karyotype* \\
\hline $\begin{array}{r}1 \\
2 \\
3 \\
4 \\
5 \\
6 \\
7 \\
8 \\
9 \\
10 \\
11 \\
12 \\
13 \\
14 \\
15 \\
16 \\
17 \\
18 \\
19 \\
20 \\
21 \\
22 \\
23\end{array}$ & \begin{tabular}{|l}
$\mathbf{C}$ \\
$\mathbf{C}$ \\
$\mathbf{C}$ \\
$\mathbf{C}$ \\
$\mathbf{C}$ \\
$\mathbf{C}$ \\
$\mathbf{C}$ \\
$\mathbf{C}$ \\
$\mathbf{C}$ \\
$\mathbf{C}$ \\
$\mathbf{C}$ \\
$\mathbf{1}$ \\
$\mathbf{C}$ \\
$\mathbf{C}$ \\
$\mathbf{C}$ \\
$\mathbf{C}$ \\
$\mathbf{C}$ \\
$\mathbf{B}$ \\
$\mathbf{C}$ \\
$\mathbf{B}$ \\
$\mathbf{B}$ \\
$\mathbf{O}$ \\
$\mathbf{C}$
\end{tabular} & $\begin{array}{l}2906 \\
2835 \\
2126 \\
2495 \\
2183 \\
2948 \\
2296 \\
2466 \\
2410 \\
2041 \\
2126 \\
1984 \\
1984 \\
\\
2566 \\
2948 \\
1871 \\
3345 \\
2240 \\
1984 \\
2013 \\
1432 \\
1928\end{array}$ & $\begin{array}{r}95 \\
153 \\
68 \\
282 \\
57 \\
719 \\
2 \\
50 \\
\\
34 \\
30 \\
34 \\
18 \\
14 \\
6 \\
37 \\
1\end{array}$ & $\begin{array}{l}29 \\
17 \\
22 \\
25 \\
39 \\
23 \\
43 \\
15 \\
18 \\
22 \\
22 \\
29 \\
42 \\
19 \\
25 \\
39 \\
32 \\
19 \\
19 \\
21 \\
27\end{array}$ & $\begin{array}{l}30 \\
18 \\
21 \\
26 \\
39 \\
25 \\
41 \\
19 \\
20 \\
27 \\
37 \\
28 \\
47 \\
29 \\
33 \\
41 \\
\\
39 \\
22 \\
19 \\
22 \\
27\end{array}$ & $\begin{array}{rr} & 41 \\
& 50 \\
& 48 \\
2 & 29 \\
1 & 24 \\
1 & 33 \\
2 & 32 \\
& 24 \\
1 & 61 \\
& 23 \\
& 25 \\
& 23 \\
& 22 \\
& 28 \\
& 22 \\
& 22 \\
& 23 \\
& 20 \\
& 20 \\
& \\
1 & 14 \\
& 21 \\
& 17 \\
29 & 1\end{array}$ & 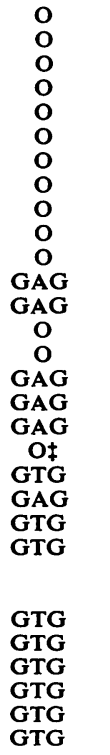 & $\begin{array}{l}47, X X,+18 \\
47, X X,+18 \\
47, X Y,+18 \\
47, X X,+18 \\
47, X X,+18 \\
47, X X,+18 \\
47, X X,+18 \\
47, X X,+18 \\
47, X X,+18 \\
47, X X,+18 \\
47, X X,+18 \\
47, X X,+18 \\
47, X X,+18 \\
47, X X,+18 \\
47, X X,+18 \\
47, X Y,+18 \\
47, X X,+18 \\
47, X Y,+18 \\
47, X Y,+18 \S \\
47, X X,+18 \\
47, X Y,+18 \\
47, X Y,+18 \\
46, X X,-13, t \\
(13 ; 18)(p 11 ; \\
\text { q11) } \\
47, X Y,+18 \\
47, X Y,+18 \\
47, X X,+18 \\
47, X Y,+18 \\
47, X X,+18 \\
47, X X,+18\end{array}$ \\
\hline
\end{tabular}

* Paris Conference (1971) Standardization in Human Cytogenetics. Birth Defects: Original Article Series Vol. VIII, No. $7,1972$.

†Paris Conference (1971) Supplement (1975) Standardization in Human Cytogenetics. Birth Defects: Orignal Article Series Vol. XI, No. 9, 1975. $\ddagger \mathbf{O}=$ orcein; $\mathbf{G A G}=\mathbf{G}$ bands by acetic saline using Giemsa; $\mathbf{G T G}=\mathbf{G}$ bands by trypsin using Giemsa; B, Black; C, Caucasian; $O$, Oriental. 8 Chromosomes done at Walter Reed Hospital.

\|Necropsy. 
Table 4 Race, birthweight, life span, parental age, and chromosomal findings of 19 cases of trisomy 13

\begin{tabular}{|c|c|c|c|c|c|c|c|c|c|}
\hline $\begin{array}{l}\text { Case } \\
\text { no. }\end{array}$ & Race & $\begin{array}{l}\text { Birthweight } \\
(\mathrm{g})\end{array}$ & $\begin{array}{l}\text { Life span } \\
\text { (days) }\end{array}$ & $\begin{array}{l}\text { Mother's age } \\
(y)\end{array}$ & $\begin{array}{l}\text { Father's age } \\
(y)\end{array}$ & $\begin{array}{l}\text { Cel } \\
46\end{array}$ & $\begin{array}{l}\text { ounts } \\
47\end{array}$ & $\begin{array}{l}\text { Type } \\
\text { banding* }\end{array}$ & Karyotype $\dagger$ \\
\hline $\begin{array}{l}1 \\
2 \\
3 \\
4\end{array}$ & $\begin{array}{l}\mathbf{C} \\
\mathbf{C} \\
\mathbf{C} \\
\mathbf{C}\end{array}$ & $\begin{array}{l}2466 \\
3487 \\
2381 \\
2270\end{array}$ & $\begin{array}{l}795 \\
116\end{array}$ & $\begin{array}{l}21 \\
23 \\
19 \\
26\end{array}$ & $\begin{array}{l}22 \\
26 \\
18 \\
27\end{array}$ & 25 & $\begin{array}{l}26 \\
25 \\
23\end{array}$ & $\begin{array}{l}\text { O‡ } \\
\text { O } \\
\text { GAG } \\
\text { GTG }\end{array}$ & $\begin{array}{l}47, X X,+D \\
47, X Y,+D \\
47, X X,+D \\
46, X Y,-14, t(13 ; 14)(13 q \text { ter } \rightarrow \\
\text { cen } \rightarrow 14 \text { qter)mat }\end{array}$ \\
\hline 5 & C & 2835 & & 20 & 19 & & 15 & GAG & $47, X X,+D$ \\
\hline 6 & $\mathbf{C}$ & 2325 & 85 & 33 & 30 & & 24 & GAG & $47, X X,+D$ \\
\hline 7 & C & 2580 & 202 & 23 & 22 & 25 & & o & $46, X X,-D, t(D ; D)$ \\
\hline 8 & C & 2098 & 31 & 22 & 28 & & 24 & o & $46, X X,+D$ \\
\hline 9 & C & 2381 & 63 & 25 & 29 & & 11 & GAG & $47, X Y,+D$ \\
\hline 10 & C & 2466 & 113 & 25 & 26 & & 24 & GTG & $47, X Y,+13$ \\
\hline 11 & C & 1814 & 0.08 & 25 & 28 & 14 & & GAG & $\begin{array}{l}46, X X,-13, t(13 ; 13)(13 q \text { ter } \rightarrow \\
\text { cen } \rightarrow 13 q \text { qter })\end{array}$ \\
\hline 12 & C & 2750 & & 38 & 42 & 19 & & GTG & $\begin{array}{l}46, X Y,-13, t(13 ; 13)(13 q \text { ter } \rightarrow \\
\text { cen } \rightarrow 13 \text { qter })\end{array}$ \\
\hline $\begin{array}{l}13 \\
14\end{array}$ & $\stackrel{\mathbf{1}}{\mathbf{3}} \mathbf{C}$ & $\begin{array}{l}1687 \\
2523\end{array}$ & 24 & $\begin{array}{l}32 \\
32\end{array}$ & $\begin{array}{l}51 \\
30\end{array}$ & & $\begin{array}{r}8 \\
10\end{array}$ & $\begin{array}{l}\text { GTG } \\
\text { GTG }\end{array}$ & $\begin{array}{l}47, \mathbf{X X}+13 \\
47, \mathbf{X X}+13\end{array}$ \\
\hline 15 & $\mathbf{C}$ & 1928 & 51 & 25 & 25 & 13 & & GTG & $\begin{array}{l}46, X Y,-14, t(13 ; 14)(13 q \text { ter } \rightarrow \\
\text { cen } \rightarrow 14 \text { qter })\end{array}$ \\
\hline 16 & C & 3175 & 12 & 18 & 19 & 24 & & GTG & $\begin{array}{l}46, X X,-22, t(13 ; 22)(13 q \text { ter } \rightarrow \\
\text { cen } \rightarrow 22 \text { qter }) \text { mat }\end{array}$ \\
\hline 17 & C & $<2268$ & & 20 & & 12 & & GTG & $\begin{array}{l}46, X X,-14, t(13 ; 14)(13 q t e r \rightarrow \\
\text { cen } \rightarrow 14 \text { qter })\end{array}$ \\
\hline $\begin{array}{l}18 \\
19\end{array}$ & $\begin{array}{l}\text { C } \\
\mathbf{B}\end{array}$ & $\begin{array}{l}3175 \\
4394\end{array}$ & $\begin{array}{r}3 \\
27\end{array}$ & $\begin{array}{l}25 \\
22\end{array}$ & $\begin{array}{l}29 \\
27\end{array}$ & 11 & 12 & $\begin{array}{l}\text { GTG } \\
\text { GTG }\end{array}$ & $\begin{array}{l}47, X Y,+13 \\
46, X Y, \operatorname{der}(8), t(8 ; 13)(p 23 ; q 14) \\
\text { mat }\end{array}$ \\
\hline
\end{tabular}

ADDENDUM

Totals: Birthweight, males (8) $2768 \pm 857$; females (11) $<2442 \pm 411$. Life span, $252 \pm 545$. Mother's age, $24 \cdot 9 \pm 5 \cdot 3$. Father's age, $27 \cdot 7 \pm 8 \cdot 0$.

Translocations: Birthweight, males (4) $2835 \pm 1092$; females (4) $<2459 \pm 571$. Life span, males $65 \pm 46$, females, $71 \pm 113$. Mother's age, males $\subseteq$

$28 \pm 7$, females, $21 \pm 3$, males and females, $24 \cdot 6 \pm 6 \cdot 0$. Father's age, males, $30 \pm 8$, females, $23 \pm 5$.

Primary trisomies: Birthweight, males (4) $2877+540$, females (7) $2331+361$. Life span, males $74 \pm 53$, females, $589 \pm 858$. Mother's age, males

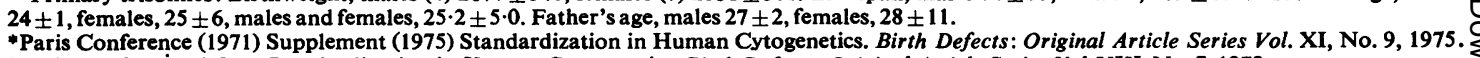
†Paris Conference (1971) Standardization in Human Cytogenetics. Birth Defects: Original Article Series Vol. XIII, No. 7, 1972.

$\ddagger O=$ orcein $; \mathbf{G A G}=\mathrm{G}$ bands by acetic saline using $\mathrm{Giemsa} ; \mathrm{GTG}=\mathrm{G}$ bands by trypsin using $\mathrm{Giemsa}$.

SD for males larger than for females. Trisomy 18 displayed a lower average birthweight than trisomy 13. Mean parental age was under $\mathbf{3 0}$ for both conditions and both parents were generally in the same age group. The sex ratio for trisomy 18 was 22 females :7 males $(75.9 \% \mathrm{~F})$ and for trisomy 13,11 females : 8 males $(57 \% \mathrm{~F})$. The life span was the most variable of the listed factors, ranging from under 1 day to $5 \cdot 5$ years for trisomy 13 and 1 day to almost 2 years for trisomy 18.

A comparison of the birthweights and mean maternal and paternal ages of the primary and tertiary trisomy 13 patients revealed no significant differences. Data on longevity were available for 5 patients with translocations of chromosomes 13 and 8 primary trisomy 13 patients. There was a pronounced difference in life span, but considerable variability within each group makes the significance of this finding questionable.

\section{CYTOGENETIC FINDINGS}

Chromosome studies in these patients were carried out mainly on 72-hour peripheral blood cultures. In 3 instances uncultured bone marrow specimens were treated with colcemide for 1 hour and tixed immediately to provide chromosomal evaluation $\stackrel{\mathbb{D}}{\longrightarrow}$ within several hours of obtaining the sample. Before $\overrightarrow{\overrightarrow{0}}$ 1971 all preparations were stained with aceto-orcein 3 (O) and after 1971 by G-banding [GTG] (Wang and Palmer, 1974).

The results are summarised in Tables 3 and 4 and the Figure. Among the 19 patients with trisomy 13 syndrome, 7 had Robertsonian translocations and 3 one chromosome was derived from a reciprocal translocation of chromosomes 8 and 13 carried $\frac{\circ}{3}$ maternally $t(8 ; 13)(p 23 ; q 14)$, [case 19]. Of the centric fusion translocation 3 involved chromosomes 13 and 5 14 (cases $4,15,17$ ), one 13 and 22 (cases 16), and 2D involved two number 13 chromosomes (cases 11 and 12). One translocation studied before banding was $N$ identified by group only (case 7). Of the 7 Robertsonian translocations, 2 were familial.

Only one translocation was found in the $29 \mathrm{c}$ patients with Edwards syndrome (case 23). It was? a de novo translocation involving chromosomes 130 and 18 , the breakpoint being at or close to the centro- $\mathbb{D}$ mere in both chromosomes $(\mathrm{t} 13 ; 18)(\mathrm{p} 11 ; \mathrm{q} 11)$. Identification of the extra chromosomal segment as $18 \mathrm{q}$ was based on the pattern of banding seen with GTG as well as on RHG banding. 

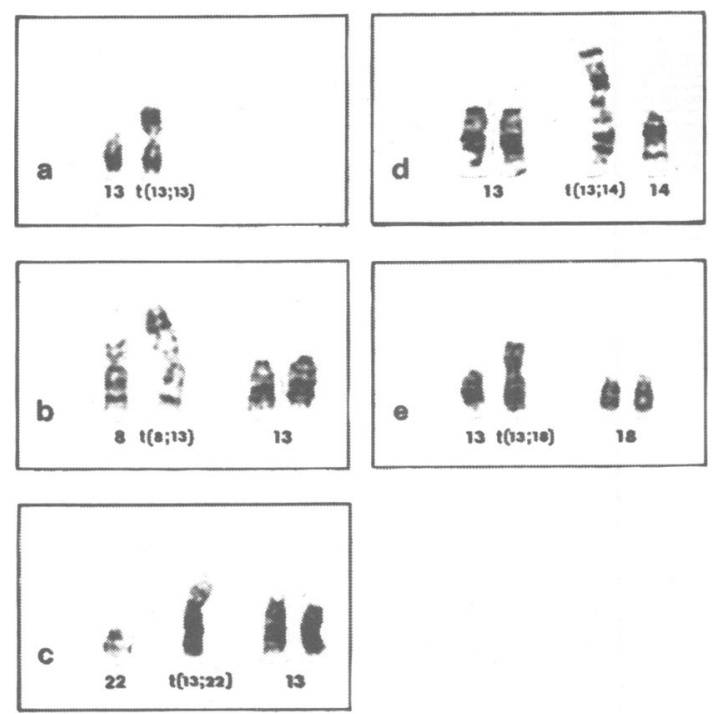

Fig. Translocations seen in patients with clinical findings of trisomy 13 or 18 . (a) $t(13 ; 13)$ translocation $(13 q t e r \rightarrow$ cen $\rightarrow 13$ qter $)$ [case 11]. (b) $t(8 ; 13)(p 23 ; q 14)$ mat translocation [case 19]. (c) $t(13 ; 22)(13 q t e r \rightarrow$ cen $\rightarrow 22 q t e r)$ mat [case 16]. (d)t $(13 ; 14)(13 q$ ter $\rightarrow$ cen $\rightarrow 14 q$ ter $)$ mat [case 4]. (e) $t(13 ; 18)(p 11 ; q 11)$.

\section{DERMATOGLYPHIC FIN DINGS}

The dermatoglyphic characteristics are summarised in Tables 5 and 6 and include many of the features noted in the review of Preus and Fraser (1972). Dermatoglyphic analysis was complicated by the flexion deformities of the hands and dermal ridge hypoplasia which was more severe in trisomy 18. The most characteristic dermatoglyphic finding in trisomy 13 was hallucal fibular arches $\left(A^{f}\right)$; in a number of instances the ridges bend proximally in the hallucal area in a tibial direction to form an $S$ pattern $\left(A^{f} s\right)$. In some cases the arch was more tented and the proximal tibial course of the ridges resulted in a very large proximally located tibial loop $\left(L^{t} p\right)$. Other frequent findings were radial loops on the ring and/or little fingers, palmar crease anomalies, very distal $\left(\mathrm{t}^{\prime \prime}\right)$ axial triradii, radial displacement of the $a$ triradius, and thenar patterns. The least characteristic case of trisomy 13 from a dermatoglyphic standpoint (case 19) carried a chromosomal translocation. Trisomy 18 was characterised by a high frequency of simple arches on both fingers and toes. Other helpful features included radial loops on the thumbs, single flexion creases of the little finger, simian creases, and, less commonly, hallucal arches and missing digital triradii. The patterns on the big toe were exclusively arch patterns, and all cases had at least one fingertip arch. The absence of arches of the big toe and presence of non-arch patterns on all fingers is strong evidence against a diagnosis of trisomy 18.

\section{NECROPSY FINDINGS}

The necropsy findings in both groups of trisomic patients are summarised in Table 7 . The difficulty that was often found in pinpointing the cardiac lesion clinically in either group of patients is mirrored in the variety of disorders affecting the heart and great vessels. Persistent ductus arteriosus and some form of interventricular septal defect were almost universal in both types of trisomic patients. Valvular, defects, pulmonary or aortic stenosis, and malposition of the great vessels probably contributed to the dilatation and hypertrophy of the chambers of the heart and to the passive congestion of most other organs which was frequently seen. These abnormalities undoubtedly also contributed to the cardiac failure which was very often clinically apparent and listed as the cause of death of these infants. Double uterus, cervix, and vagina were common findings in trisomy 13. Abnormalities of the brain were almost universal and all 5 patients with trisomy 13 had some form of holoprosencephaly. Case 19 was the only child of either series to have hydrocephalus.

\section{MISCELLANEOUS}

In 1976 follow-up letters were sent to all parents, and 18 replies were received. Five of the mothers of trisomy 18 children and three of the mothers from the trisomy 13 series subsequently gave birth to normal children. There were 11 first-born children in each series and no information on birth order was available on 4 . The births occurred in the following months for trisomy 18 (28 cases) and 13 (18 cases), respectively: January, 1, 2; February, 2, 1; March, 4, 3; April, 4, 0; May, 3, 1; June, 0, 0; July, 1, 2; August, 2, 1; September, 0, 1; October 4, 3; November, 7,1 ; December, $0,3$.

\section{Discussion}

In attempting to compare our series with those reported in the literature, we were beset with a number of problems. The first resulted from the different ways findings have been combined by the various authors (McKusick, 1969). We attempted to combine findings into clinically useful categories that aided us and would aid others in the diagnosis and have left a comprehensive review of the myriad individual variations of, e.g. ear folding or types of murmurs for others. This still leaves an impressive array of single abnormalities. The second problem stems from the fact that summary papers often and inevitably plough the same ground. Third, it is not 


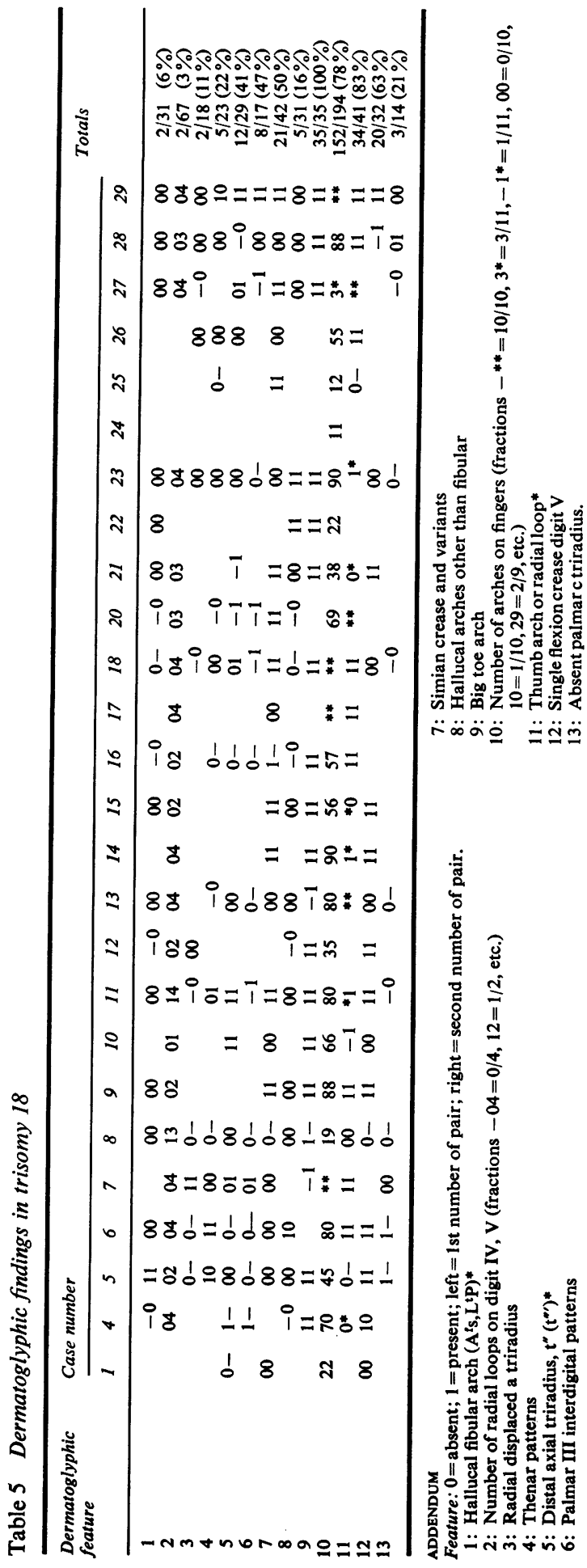


Table 6 Dermatoglyphic findings in trisomy 13

\begin{tabular}{|c|c|c|c|c|c|c|c|c|c|c|c|c|c|c|c|c|}
\hline \multirow{2}{*}{$\begin{array}{l}\text { Dermato- } \\
\text { glyphic } \\
\text { feature }\end{array}$} & \multicolumn{15}{|c|}{ Case number } & \multirow[t]{2}{*}{ Totals } \\
\hline & 1 & 2 & 3 & 4 & 5 & 6 & 7 & 8 & 9 & 13 & 14 & 15 & 16 & 17 & 19 & \\
\hline $\begin{array}{r}1 \\
2 \\
3 \\
4 \\
5 \\
6 \\
7 \\
8 \\
9 \\
10 \\
11 \\
12 \\
13\end{array}$ & $\begin{array}{l}03 \\
11 \\
00 \\
11 \\
11 \\
11\end{array}$ & $\begin{array}{l}1 * \\
14 \\
-1 \\
-0 \\
-0 \\
-1 \\
00 \\
00 \\
00 \\
00 \\
-0\end{array}$ & $\begin{array}{l}01 \\
44 \\
10 \\
11 \\
1- \\
01 \\
11 \\
00 \\
01 \\
00 \\
00 \\
00 \\
00\end{array}$ & $\begin{array}{l}1 * \\
04 \\
11 \\
10 \\
* 1 \\
11 \\
11 \\
00 \\
00 \\
00 \\
00 \\
00 \\
00\end{array}$ & $\begin{array}{l}* * \\
23 \\
01 \\
10 \\
* * \\
01 \\
10 \\
00 \\
11 \\
19 \\
00 \\
00 \\
00\end{array}$ & $\begin{array}{l}11 \\
22 \\
11 \\
11 \\
* * \\
1- \\
11 \\
00 \\
10 \\
18 \\
10 \\
0-\end{array}$ & $\begin{array}{l}10 \\
01 \\
0- \\
01 \\
01 \\
11 \\
05 \\
00\end{array}$ & $\begin{array}{l}11 \\
11 \\
00 \\
11 \\
29 \\
10 \\
00 \\
00\end{array}$ & $\begin{array}{l}* 0 \\
02 \\
01 \\
-0 \\
* * \\
-1 \\
11 \\
01 \\
07 \\
0- \\
-0\end{array}$ & $\begin{array}{l}-0 \\
02 \\
-1 \\
-1 \\
-1 \\
-0 \\
-1 \\
-0 \\
-1 \\
14 \\
-0 \\
-0\end{array}$ & $\begin{array}{l}11 \\
33 \\
-0 \\
-0 \\
-1 \\
11 \\
00 \\
00 \\
07 \\
-0 \\
-0 \\
-0\end{array}$ & $\begin{array}{l}* * \\
24 \\
00 \\
11 \\
01 \\
11 \\
00 \\
00 \\
00 \\
10 \\
00 \\
-0 \\
00\end{array}$ & $\begin{array}{l}11 \\
24 \\
11 \\
00 \\
11 \\
11 \\
00 \\
00 \\
00 \\
00 \\
00 \\
00 \\
00\end{array}$ & $\begin{array}{l}-{ }^{*} \\
24 \\
11 \\
00 \\
11 \\
01 \\
11 \\
-0 \\
-0 \\
1 * \\
00 \\
00 \\
00\end{array}$ & $\begin{array}{l}00 \\
14 \\
11 \\
-0 \\
00 \\
00 \\
11 \\
00 \\
19\end{array}$ & $\begin{array}{l}19 / 26(73 \%) \\
20 / 46(43 \%) \\
19 / 27(70 \%) \\
9 / 21(43 \%) \\
18 / 22(82 \%) \\
17 / 24(71 \%) \\
20 / 28(71 \%) \\
2 / 26(8 \%) \\
9 / 20(45 \%) \\
8 / 126(6 \%) \\
2 / 22(9 \%) \\
1 / 19(5 \%) \\
0 / 23(0 \%)\end{array}$ \\
\hline
\end{tabular}

See footnote to Table 5 .

always clear whether an author has summarised findings as a fraction of the total number of cases in the series or as a fraction of the cases in which a particular finding was mentioned as present or not present. We have used the former method in Tables 1 to 7 and both methods in Table 8. In the latter our series is compared with some literature surveys. It seems that our findings are generally consonant with the broad ranges reported by Smith (1976) and Bergsma (1973), when allowance is made for the errors introduced by physicians who failed to note the absence of a particular finding and our refusal to accept 'normal' as a sufficient description.

Certain findings present problems of definition because well-established normal measurements or criteria were lacking or not known to the examiners. An example of this would be 'narrow' (which dimension?) palpebral fissures in trisomy 18 . Changes in findings (hypertonicity after the neonatal period in trisomy 18) may have been overlooked because the baby was not seen by the same physicians each time. These oversights decrease the reported incidence. We note particularly the following deviations in our study as compared with some others (listed in Table 8): the incidence of umbilical hernia is low for unknown reasons. Several instances of inguinal hernia are noted in the addenda to Tables 1 and 2 but they are not sufficient to account for the discrepancies, even when other authors have combined the 2 types of hernia. Micrognathia is a variable finding and there are no good objective criteria for its diagnosis. It seems to have been missed often in our series or overdiagnosed in the others. It appears that prominent occiput was diagnosed as often by us as by others in trisomy 18 but prominent heels were reported less often in trisomy 13. The data on cryptorchidism seem firm and the incidence is definitely less than the $100 \%$ in trisomy 18 males reported in the literature (see Table 8 for references). In only one of our cases did the observers fail to mention the location of the testes. On the other hand, the $100 \%$ reported incidence of cryptorchidism in trisomy 13 males is confirmed. A short hallux may have been grossly underestimated in our series. In evaluating these data, it is important to note that, whereas a small chin may be missed or not remarked in the notes, polydactyly and cryptorchidism are features too prominent for such errors, since inspection of the hands and testes are included in most complete examinations and those abnormalities are unlikely to be misdiagnosed. The data on hypotelorism is confusing. Smith (1976) states that either hypo- or hypertelorism may occur in trisomy 13 whereas some authors, such as Bergsma (1973) and Taylor (1968), give a high incidence for hypertelorism. The incidences may be as much a commentary on what people look for as on what is found on routine examination.

It is apparent from the Tables as well as from the published reports, that each of these syndromes presents a number of salient features, a combination of which is often diagnostic. Given the proper juxtaposition of findings it is probably easier for the uninitiated to diagnose trisomy 13 than trisomy 18 . This is because the constellation of microphthalmia, abnormal ears, cleft palate, and scalp defects in a microcephalic child is striking and almost pathognomonic, whereas the impression made by the trisomy 18 infant is more subtle. Children with either syndrome had cardiac abnormalities. Likewise ear abnormalities including low set and various deformities of the pinnae occurred in all the trisomy 18 and almost all the trisomy 13 patients. Polydactyly was moderately common (mentioned in $58 \%$ ) in trisomy 13 and rare $(7 \%)$ in trisomy 18 . These and other features have been commented on extensively by a number of authors.

Attempts have been made to use primary regular trisomies to localise specific functions or structures to 
Table 7 Principal findings at necropsy in 10 cases of trisomy 18 and 5 cases of trisomy 13

\begin{tabular}{|c|c|c|c|c|c|c|c|c|c|c|c|c|c|c|c|c|}
\hline \multirow[t]{3}{*}{$\cdot$} & \multicolumn{11}{|c|}{ Trisomy 18} & \multicolumn{5}{|c|}{ Trisomy 13} \\
\hline & \multicolumn{11}{|c|}{ (Case no.) } & \multicolumn{5}{|c|}{ (Case no.) } \\
\hline & 1 & 3 & 8 & 9 & 12 & 13 & 17 & 18 & 20 & 22 & 25 & 8 & 11 & 16 & 18 & 19 \\
\hline $\begin{array}{l}\text { Heart and great vessels } \\
\text { Patent foramen ovale }\end{array}$ & 1 & 1 & & & & & 1 & & & & 1 & 1 & 1 & & & \\
\hline Persistent ductus arteriosus & 1 & 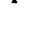 & 1 & 1 & 1 & 1 & 1 & 1 & 1 & & 1 & 1 & 1 & 1 & & 1 \\
\hline $\begin{array}{l}\text { Dilated/hypertrophied rt. } \\
\text { ventricle }\end{array}$ & 1 & 1 & 1 & & 1 & & 1 & 1 & & & & 1 & 1 & 1 & 1 & 1 \\
\hline $\begin{array}{l}\text { Dilated/hypertrophied rt. } \\
\text { atrium }\end{array}$ & 1 & 1 & 1 & & & 1 & & 1 & & & & & & & & \\
\hline Dilated pulmonary artery & 1 & 1 & 1 & & & 1 & 1 & 1 & & & & & & & & \\
\hline $\begin{array}{l}\text { Intraventricular septal } \\
\text { defect }\end{array}$ & 1 & 1 & 1 & 1 & 1 & 1 & & 1 & 1 & & 1 & 1 & 1 & 1 & 1 & \\
\hline Atresia mitral valve & 1 & & & & & & 1 & & 0 & & 1 & $\mathbf{1}$ & 1 & 1 & 1 & \\
\hline Overriding aorta & 1 & & & & & & & & & & & 1 & 1 & & & \\
\hline & 1 & & 1 & & 1 & & 1 & & 1 & & & & & & & \\
\hline $\begin{array}{l}\text { Coarctation aorta } \\
\text { Abnormal aortic valve }\end{array}$ & $\begin{array}{l}1 \\
1\end{array}$ & & & 1 & & & & & 0 & & & & & & & \\
\hline & & & 1 & & 1 & & 1 & & 1 & & & & & & & \\
\hline ventricle & & & 1 & & 1 & 1 & & 1 & 0 & & & & & & & \\
\hline $\begin{array}{l}\text { Abnormal tricuspid valve } \\
\text { Hypoplasia heart }\end{array}$ & & & & 1 & & 1 & & & $\mathbf{0}$ & & & 1 & & & & \\
\hline $\begin{array}{l}\text { Abnormal origin subclavian } \\
\text { artery }\end{array}$ & & & & & 0 & 1 & 1 & & 0 & & & & & & & \\
\hline $\begin{array}{l}\text { Other } \\
\text { Lungs }\end{array}$ & 1 & & 1 & & 1 & & 1 & 1 & 1 & & & 1 & 1 & & & \\
\hline $\begin{array}{l}\text { Congestion/pneumonia } \\
\text { GI }\end{array}$ & 1 & 1 & 1 & 1 & 1 & 1 & 1 & 1 & 1 & & & & & & & \\
\hline Meckel's diverticulum & 1 & & & & & & & & & & & 1 & & 1 & & \\
\hline $\begin{array}{l}\text { Congestion/fibrosis } \\
\text { Pancreas }\end{array}$ & 1 & & & & 1 & 1 & 1 & 1 & $\mathbf{0}$ & & & & & & & \\
\hline $\begin{array}{l}\text { Accessory spleen } \\
G U\end{array}$ & & & & & & & & & & & & 1 & 1 & 1 & & \\
\hline Horseshoe kidney & & & & 1 & 1 & & 1 & 1 & & & & & & & & \\
\hline $\begin{array}{l}\text { Cysts of kidney } \\
\text { Hydronephrosis }\end{array}$ & & & & & & 1 & & & & & & 1 & & & 1 & 1 \\
\hline $\begin{array}{l}\text { Hydronephrosis } \\
\text { Bifid ureters }\end{array}$ & & 1 & & & & & & & & & & & 1 & & & 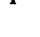 \\
\hline $\begin{array}{l}\text { Double uterus, etc. } \\
\text { Brain }\end{array}$ & & & & $\mathbf{0}$ & & & & & & & & 1 & 1 & 1 & & \\
\hline Abnormal & 1 & & & 1 & 1 & 1 & 1 & 1 & & 0 & & 1 & 1 & 1 & & 1 \\
\hline
\end{tabular}

ADDENDUM

Additonal findings: Trisomy 18-(1) small left ventricle, focal atelectasis lung, microscopical haemangioma of liver, acinar atrophy, fibrosis and ductule proliferation and dilatation of pancreas, cortical nodules of adrenal glands, hypoplasia of cerebellum and pons, neuraxial dysplasia of brain; (3) slight bronchopneumonia, hypertrophy of wall of urinary bladder; (8) abnormal configuration of liver, atrioventricularis communis, persistent left superior vena cava draining into left atrium, tricuspid pulmonary valve, diffusely haemorrhagic lungs, double renal pelvis, and bifid ureter; (9) hypoplasia and atresia of aorta, dilatation, trabeculation, and hyertrophy of urinary bladder, bilobed right lung, cyst of right ovary, stenosis of foramen magnum, focal compression of spinal cord; (12) dextroposition aorta, anomalous insertion papillary muscle of tricuspid valve, $\vec{\theta}$ bicuspid aortic and pulmonary valves, shortened chordae tendineae, and anomalous insertion of mitral valve, cerebral heterotopia, hypoplasia optic nerves, disorganisation of cortical nuclear layer, mildly abnormal gyrations; (13) pulmonary atresia, hypoplastic right ventricle, anomalous origin and shortening of chordae tendineae of tricuspid leaflets, right subclavian artery originates from descending aorta, partial absence corpus callosum, diffusely abnormal cerebral gyration, abundant extramedullary haematopoiesis in liver, minute areas of pulmonary haemorrhage, focal $\bigcirc$ fibrosis left ventricle, mucocyst formation kidneys; (17) mitral atresia, hypoplasia left ventricle, right ventricle functioning as single ventricle, aortic stenosis, bicuspid aortic valve, hypoplasia of aorta, partial anomalous venous return, bronchopneumonia, inappropriate gyrations of brain, heterotopia and necrosis, multiple focal with calcifications, small thin corpus callosum, 2 umbilical vessels; (18) dextroposition of aorta, atresia pul- $\bigcirc$ monary valve, pulmonary stenosis, eventration left lobe of liver and upper pole of spleen through left posterolateral diaphragm, atelectasis of lungs, congestion of kidneys, absent corpus callosum and sulcation perpendicular to the long axis of frontal and temporal lobes; (20) bicuspid $D$ aortic valve, hypoplastic aortic arch, aplsia right umbilcal artery, bilateral atelactasis of lung, paragastric enteric cyst, pancreatic heterotopia $C$ (duodenal and jejunal), mild fatty metamorphosis and acute congestion of the liver, thymic, thyroid, and sternal hypoplasia, brain not abnormal: (22) bilateral absence radius and ulna; (25) tracheoesophageal fistula, haemorrhage right middle and left lower lobe of lung, fetal endocarditis of $\mathcal{N}$ mitral and tricuspid valves, small benign simple cyst of thyroid.

Additional findings: Trisomy 13-(8) bileaflet tricuspid valve, fusion 2 cusps of pulmonary valve, malplacement of duodenum, malplacement of $N$ colon behind small bowel, double vagina, uterus, and cervix, left posterior eventration of diaphragm with spleen tip in left thorax, bilateral hydro- $N$ salpinx, ? mesonephric cysts, multiple dermoid cysts in posterior pelvis, atelectasis of lungs, lobar holoprosencephaly, (11) pulmonary stenosis, $\omega$ absent left coronary artery, acessory spleens, bifid ureters, alobar holoprosencephaly; (16) accessory spleen, dilatation of calyces and pelves both kidneys, juxtarectal cystic teratoma, focal interstitial haemorrhage of pancreas, anatomical fusion of portion of pancreas in spleen, status post colostomy, bilateral peripheral apenencephaly; $(18)$ prolapse septal leaflet of tricupsid valve into left ventricle, elongation and anterior disclocation 6

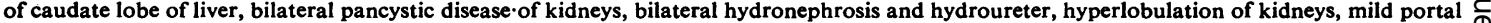
fibrosis of liver, dilatation of appendix with proximal obstruction with numerous tiny subserosal nodular lesions, segmental necrosis of gastro- $\mathscr{\curvearrowright}$ intestinal mucosa; (19) bilateral hydronephrosis, distinct atrophy of cerebrum, especially forebrain, absent ductus sylvius, pronounced hydrocephalus, absent left lateral and third ventricles and hypoplasia right lateral ventricle, bilateral absence of fosal ganglia, bilateral absence olfactory nerve, absence cerebral hemispheres. 
individual chromosomes (Baughan et al., 1969; Hall and Dahlqvist, 1971; Sabater et al., 1971; Cote and Edwards, 1976) and translocations for localising discrete functions to specific areas on an individual chromosome (Noel et al., 1976). In view of this it is interesting to compare the translocation with the primary trisomies in our series.

Case 23 represents a de novo translocation with partial trisomy $18 \mathrm{q}$ involving chromosomes 13 and 18 , with the breakage at or near the centromere of chromosome 13. Losses of $13 \mathrm{p}$ generally do not result in clinical abnormalities as most of this region codes for ribosomal RNA and D group variants minus short arms, as well as carriers of Robertsonian translocations involving D group members, show no clinical abnormality. Case 23 with $18 q$ but not $18 p$ in excess had most of the common features of the syndrome with the exception of prominent heels, high palate, and shortened survival.

Translocations were more common among our trisomy 13 patients than among the trisomy 18 cases and represented $42 \%$ of that series. The incidence

Table 8 Comparison of clinical features reported here with summaries from the literature

\begin{tabular}{|c|c|c|c|c|c|c|c|c|}
\hline \multirow[t]{2}{*}{ Feature } & \multicolumn{8}{|c|}{ TRISOMY 18} \\
\hline & $(a)^{*}$ & (b) & (c) & $(d)$ & (e) & $(f)$ & $(g)$ & (h) \\
\hline \multicolumn{9}{|c|}{ A: Generally common to both trisomy 13 and 18} \\
\hline $\begin{aligned} 1 & \text { Ear abnormalities } \\
2 & \text { Cardiac abnormalities } \\
3 & \text { Micrognathia } \\
4 & \text { Overlapping fingers } 1 \\
5 & \text { Microcephaly } \\
6 & \text { Prominent heels } \\
7 & \text { High/arched palate } \\
8 & \text { Microphthalmia } \\
9 & \text { Hypertonia } \\
10 & \text { Umbilical hernia } \\
11 & \text { Cryptorchidism } 8\end{aligned}$ & $\begin{aligned}>80 \\
>95 \\
>80 \\
>80 \\
\\
50-80 \\
80 \\
10-50 \\
50-80^{4} \\
50-80 \\
100\end{aligned}$ & $\begin{aligned}> & 50 \\
> & 50 \\
> & 50 \\
> & 50 \\
& 10-50 \\
& 10-50 \\
& 50 \\
< & 10 \\
> & 503 \\
> & 50 \\
> & 50\end{aligned}$ & $\begin{array}{r}85 \\
92 \\
100 \\
77 \\
55 \\
44 \\
15 \\
\\
92 \\
15\end{array}$ & $\begin{array}{l}99 \\
\text { Most } \\
97 \\
94\end{array}$ & $\begin{array}{r}88 \\
85 \\
92 \\
89 \\
8 \\
77\end{array}$ & $\begin{array}{l}98 \\
95 \\
96 \\
94\end{array}$ & $\begin{array}{r}100 \\
93 \\
96 \\
100 \\
70 \\
87 \\
87 \\
82 \\
60 \\
67 \\
43\end{array}$ & $\begin{array}{r}100 \\
93 \\
86 \\
90 \\
65 \\
48 \\
48 \\
31 \\
21 \\
14 \\
43\end{array}$ \\
\hline
\end{tabular}

B: More common in trisomy 18

12 Prominent occiput

13 Dislocated hips ${ }^{2}$

14 Hypoplastic nails

15 Club foot deformities

16 Wide-spaced nipples

17 Hypertrophic clitoris8

18 Hammer toe

19 Narrow palpebral fissures

20 Short sternum

21 Small mouth

22 Excess skin-neck

23 Seizures

24 Abnormal head

25 Hypoplastic genital labia8

26 Hypotonia

27 Duplicate urinary system

28 Upward palpebral fissures

29 Epicanthal folds

30 Syndactyly

31 Short hallux

32 Downward palpebral fissures

$\begin{array}{cc}>80 & >50 \\ >80 & >50 \\ 10-50 & 50 \\ 40-60 & 10-50 \\ 10-50 & 10-50 \\ & 10-50 \\ 50-809 & >509 \\ & >50 \\ >80 & >50 \\ 40-60 & >50 \\ & >50\end{array}$

$\begin{array}{rlll}15 & 87 & 68 & 92 \\ 92 & & 63 & \\ 67 & & & \\ & & & \\ 100 & 799 & 75 & \\ 50 & 87 & 68 & 85 \\ 100 & & & \\ 59 & 50 & 56 & 40\end{array}$

80

$10-50$

$50-80$

$10-50$

$50-80$

$10-50$
$>105$

10-50

$10-50$

50-809

$10-50$

70
73

$>509 \quad 73$

$>509$
$<105$

100

799

86
62

$91 \quad 69$

C: More common in trisomy 13

33 Cleft palate

34 Polydactyly

35 Scalp defects

36 Cleft lip

37 Apnoeic episodes

38 Capillary haemangiomas

39 Dextrocardia

40 Hypotelorism/hypertelorism

41 Coloboma of iris

42 Sloping forehead

43 Flat head

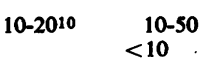

44 Hypoplastic nipples

45 Prominent nasal bridge

46 Short neck

$\begin{array}{cc} & <10 \\ 10-2010 & 10-50 \\ & \pm \\ & <10 \\ & <10 \\ & \\ 50-80 & <10\end{array}$

*(a) Berosma, 1973; (b) Smith, 1976; (c) Butler et al., 1965; (d) Taylor, 1967; (e) Taylor, 1968; (f) Taylor and Polani, 1964; (g) This paper, percentage mentioned; (h) This paper, percentage total. $1=$ or flexion deformity; $2=$ or limited abduction or flexion deformity; $3=$ after neonatal period; $4=$ after hypotonia; $5=$ upward or downward slant; $6=$ inguinal or umbilical hernia; $7=$ hypertelorism; $8=$ sex adjusted; $9.10=$ same entry. 
Table 8-continued

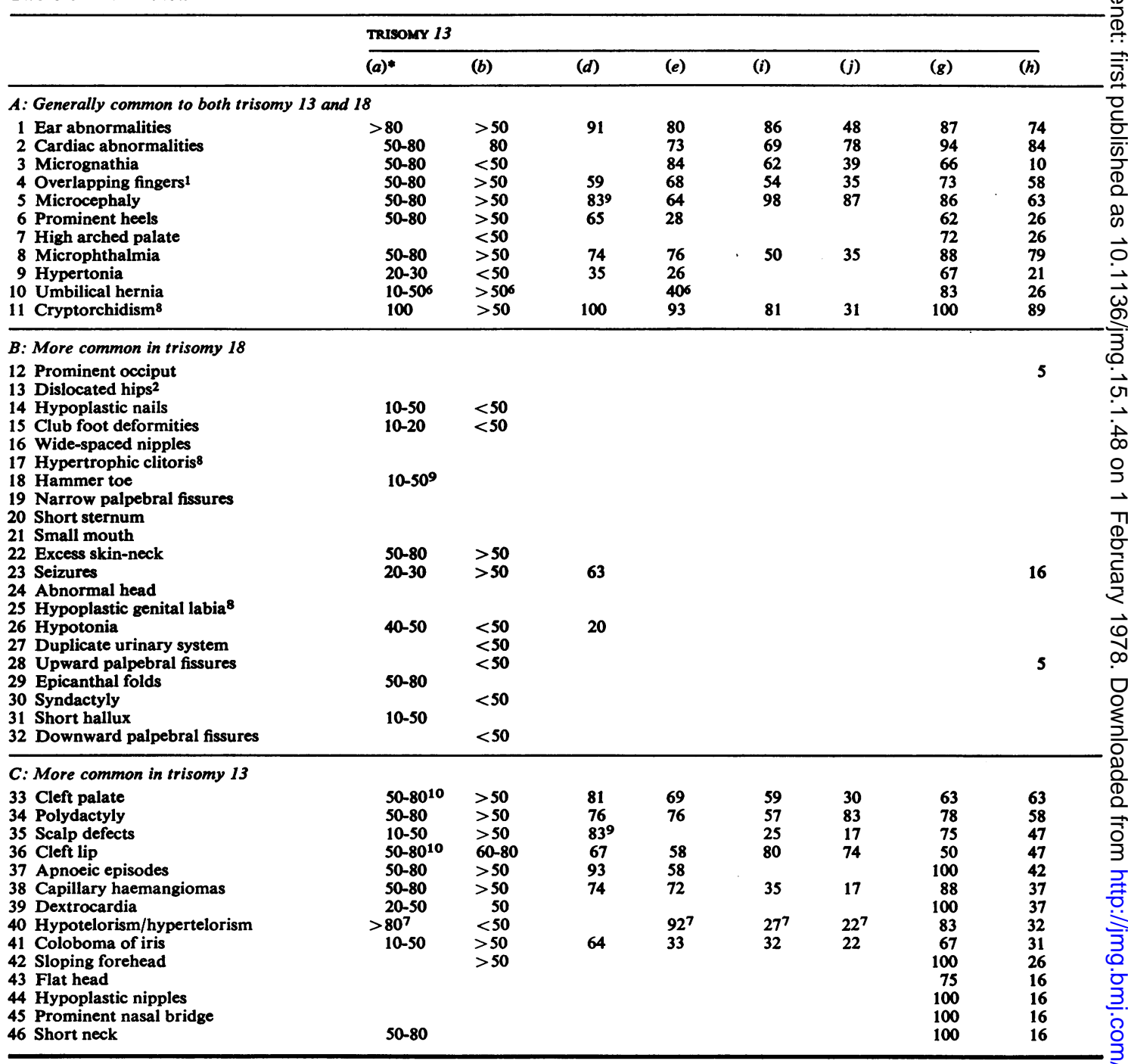

*(a) Bergsma, 1973; (b) Smith, 1976; (d) Taylor, 1967; (e) Taylor, 1968; (i) Lazyuk et al., 1974; (j) Lazyuk et al., 1974; (g) This paper, percentageo mentioned; (h) This paper, percentage total. ${ }^{1}=$ or flexion deformity; ${ }^{2}=$ or limited abduction or flexion deformity; ${ }^{3}=$ after neonatal period; $\supset$ $4=$ after hypotonia $; 5=$ upward or downward slant; $6=$ inguinal or umbilical hernia; $7=$ hypertelorism; $8=\operatorname{sex}$ adjusted; $9,10=$ same entry.

cited by Magenis et al. (1968) was $13.6 \%$ of 221 cases culled from various sources. This is related to the frequency of occurrence of Robertsonian translocations $(1: 1000)$. In our series 5 were de novo centric fusion translocation trisomies. Since the short arms of chromosome 13 have little genetic information, not only do we see a greater number of rearrangements in trisomy 13 (as contrasted to partial trisomy 18) but the genetic information contained in the unbalanced translocations and primary trisomic individuals does not differ significantly.
Thus there was no single clinical finding in which then translocation cases differed from the trisomies-only? hypotelorism $(3 / 5)$ seemed more common in trans- $N$ location patients. Case 19, the lone patient with a duplication resulting from segregation of a balanced translocation (of chromosomes 13 and 8), was theo only one with hydrocephalus. Hypotonia was present in 3 cases. Case 12 differed from the majority of the? series and also from Case 11 in the absence of a cleft palate. However a scalp defect was present and this was not mentioned in Case 11. 
The trisomies have been found in white, black, and yellow races. Though our series does not include an oriental with trisomy 13, this conjunction has been reported (Yu et al., 1970). The predominance of females in trisomy 18 is well known (Weber, 1967) as is the shortened life span in both conditions. The longest survival in this series to date ( 5.5 years, trisomy 13$)$ is exceptional but similar to that reported by Mankinen and Sears (1976). Our case differs from theirs in that microcephaly and seizures were not reported. Though Magenis et al. (1968) report longer survival in translocation as opposed to primary trisomy, our longest survivals (which weight the averages heavily) were among the primary trisomic patients. It should be noted that there was a much higher incidence of translocations ( 43 vs. $13.6 \%$ ) in the series reported here. As this is a referral institution, many of the trisomic cases born in the State may not have survived long enough to reach this hospital.

Maternal age in trisomy 13 and 18 is reported to be bimodally distributed (Magenis et al., 1968), whereas in the general population the mode is 20 to 24 years (Edwards et al., 1960; Vital Statistics of the United States, 1970). The translocation mothers cluster about a mean maternal age of 26.6 years in the trisomy 13 cases of that series and 24.6 in ours -0.6 year younger than the average age of the nontranslocation mothers (Table 4). In our series, $80 \%$ of the trisomy 13 mothers and $63 \%$ of the trisomy 18 mothers were 26 or under whereas the remainder of the trisomy 13 mothers were over 32 . There are probably not enough cases in the present series to offer firm evidence on bimodality.

Addor et al. (1975) reviewed 76 published cases of trisomy 13 in which necropsy was done. They describe and discuss the pathological findings in detail. Renal abnormalities occurred in $60 \%$ and cardiac malformations in $82 \%$ of their series and in all 5 of ours. Postmortem findings in both trisomic syndromes were reported by Taylor (1968). In consonance with her findings, in our series biseptate uterus and absent olfactory bulbs were limited to trisomy 13 and horseshoe kidney to trisomy 18 . In contrast with her report, double renal pelvis was found in one case of trisomy 18 while meningomyelocele was not seen in that condition and eventration of the diaphragm was found in trisomy 13.

Seasonal variation in births of trisomic babies has been reported (Nielsen et al., 1975). Ten of $28(36 \%)$ of our trisomy 18 babies were born between February and April whereas in the Danish series 6 of $7(86 \%)$ were born during that period of the year. Taylor's data (1968) indicate increased births from June to December $(67 \%)$ whereas $50 \%$ of our series occurred during that period. It may be coincidental that $25 \%$ of the births in our series occurred in November.
The incidence of births of trisomy 13 babies from June to November was $44 \%$ in contrast with Taylor's report (1968) of $79 \%$ during those months. Our data are thus at variance with that of Taylor (1968) for both trisomies and the Danish and Canadian experience with trisomy 18 summarised by Nielsen et al.(1975).

We would like to acknowledge the cytogenetic assistance of Judy Kojetin, Lillian Wang, and Rosalie Armstrong, and to thank Mrs Lynda Tucker for her patience and help in typing many revisions of this manuscript.

\section{References}

Addor, C., Cox, J. N., Cabrol, C., and Crippa, L. (1975). Patau's syndrome: a pathological and cytogenetic study of two cases. I. Anatomopathological aspects. Journal de Génétique Humaine, 23, 83-109.

Baughan, M. A., Sparkes, R. S., Pagila, D. E., and Wilson, M. G. (1969). Blood cell enzymes in trisomy $E(18)$ syndrome. Journal of Medical Genetics, 6, 42-47.

Bergsma, D. (1973). Birth Defects: Atlas and Compendium. Williams and Wilkins, Baltimore (The National Foundation).

Butler, L. J., Snodgrass, G. J. A. I., France, N. E., Sinclair, L., and Russell, A. (1965). E(16-18) trisomy syndrome: analysis of 13 cases. Archives of Disease in Childhood, 40, 600-611.

Cote, G. B., and Edwards, J. H. (1976). Get,etic markers in trisomies 13 and 18. Annals of Human Genetics, 39, 335-337.

Edwards, J. H., Harnden, D. G., Cameron, A. H., Crosse, V. M., and Wolff, O. H. (1960). A new trisomic syndrome. Lancet, 1, 787-790.

Hall, B., and Dahlqvist, A. (1971). Enzyme activity in D trisomies. Lancet, 2, 934.

Lazyuk, G. I., Kravtsova, G. I., Kulazhenko, V. P., Usova, Yu, I., and Usoev, S. S. (1974). Analysis of 137 cases of the trisomy-D syndrome. Soviet Genetics, 7, 1338-1349.

McKusick, V. A. (1969). On lumpers and splitters, or the nosology of genetic disease. Birth Defects: Original Article Series, 5, No. 1, 23-30.

Magenis, R. E., Hecht, F., and Milham, S., Jr. (1968). Trisomy 13(D) syndrome: studies on parental age, sex ratio, and survival. Journal of Pediatrics, 73, 222-228.

Mankinen, C. B., and Sears, J. W. (1976). Trisomy 13 in a female over 5 years of age. Journal of Medical Genetics, 13, 157-161.

Nielsen, J., Holm, V., and Haahr, J. (1975). Prevalence of Edwards' syndrome. Clustering and seasonal variation? Humangenetik, 26, 113-116.

Noel, B., Quack, B., and Rethore, M. O. (1976). Partial deletions and trisomies of chromosome 13: mapping of bands associated with particular malformations. Clinical Genetics, 9, 593-602.

Patau, K., Smith, D. W., Therman, E., Inhorn, S. L., and Wagner, H. P. (1960). Multiple congenital anomaly caused by an extra chromosome. Lancet, 1, 790-793.

Preus, M., and Fraser, F. C. (1972). Dermatoglyphics and syndromes. American Journal of Diseases of Children, 124, 933-943.

Sabater, J., Puliol, M., and Antich, J. (1971). Enzyme determinations in three cases of trisomy 18 syndrome (Edwards' syndrome). Enzyme, 12, 508-512. 
Smith, D. W. (1976). Recognizable Patterns of Human Malformations: Genetic, Embryologic, and Clinical Aspects, 2nd ed. W. B. Saunders, Philadelphia.

Taylor, A. I. (1967). Patau's, Edwards' and cri du chat syndromes: a tabulated summary of current findings. Developmental Medicine and Child Neurology, 9, 78-86.

Taylor, A. I. (1968). Autosomal trisomy syndromes: a detailed study of 27 cases of Edwards' syndrome and 27 cases of Patau's syndrome. Journal of Medical Genetics, 5, 227-252.

Taylor, A. I., and Polani, P. E. (1964). Autosomal trisomy syndromes, excluding Down's. Guy Hospital Reports, 113, 231-249.

Vital Statistics of the United States, Section I. (1970). Government Printing Office, Washington, D.C.
Wang, L. Y., and Palmer, C. G. (1974). A routine trypsin $\stackrel{\mathbb{D}}{7}$ procedure for use in banding chromosomes and auto- $\widehat{D}$ radiographs. Mammalian Chromosome Newsletter, 15, 26 .

Weber, W. (1967). Survival and sex ratio in trisomy 17-18. American Journal of Human Genetics, 19, 369-377.

Yu, F. C., Gutman, L. T., Huang, S. W., Fresh, J. W., andర Emanuel, I. (1970). Trisomy 13 syndrome in Chinese infants, clinical findings and incidence. Journal of Medical $\bar{\omega}$ Genetics, 7, 132-127.

Requests for reprints to Dr M. E. Hodes, Department of Medical Genetics, Indiana University School of Medicine, Indianapolis, Indiana 66202, U.S.A. 